\title{
Second Generation PFBC Systems
}

R\&D - Phase 2 and Phase 3

Monthly Technical Report

Reporting Period Start Date: 08/01/1999 End Date: 08/31/1999

Author: A. Robertson

Report Issue Date: 09/30/1999

DE-AC21-86MC21023--73

Foster Wheeler Development Corp.

12 Peach Tree Hill Road

Livingston, NJ 07039 
"This report was prepared as an account of work sponsored by an agency of the United States Government. Neither the United States Government nor any agency thereof, nor any of their employees, makes any warranty, express or implied, or assumes any legal liability or responsibility for the accuracy, completeness, or usefulness of any information, apparatus, product, or process disclosed, or represents that its use would not infringe upon privately owned rights. Reference herein to any specific commercial product, process, or service by trade name, trademark, manufacturer, or otherwise does not necessarily constitute or imply its endorsement by the United States Government or any agency thereof. The views and opinions of authors expressed herein do not necessarily state or reflect those of the United States Government or any agency thereof." 


\section{TECHNICAL PROGRESS REPORT NUMBER 21023R42 \\ FOR MONTH 137 (August 1999) -- PHASE 2}

When DOE funds were exhausted in March 1995, all Phase 2 activities were placed on hold. In February 1996 a detailed cost estimate was submitted to the DOE for completing the two remaining Phase 2 Multi Annular Swirl Burner (MASB) topping combustor test campaigns; in August 1996 release was received from FETC to proceed with the two campaigns to:

1. test the MASB at proposed demonstration plant full to minimum load operating conditions

2. identify the lower oxygen limit of the MASB

3. demonstrate natural gas to carbonizer fuel gas switching.

4. demonstrate operation with "low temperature" compressor discharge air rather than high temperature (. 1600EF) vitiated air.

The 18 in. MASB was last tested at the University of Tennessee Space Institute (UTSI) in a high-oxygen configuration and must be redesigned/modified for low oxygen operation. A second-generation PFB combustion plant incorporating an MASB based topping combustor will be constructed at the City of Lakeland's Mclntosh Power Plant under the U.S. DOE Clean Coal V Demonstration Plant Program. This plant will require the MASB to operate at oxygen levels that are lower than those previously tested. Preliminary calculations aimed at defining the operating envelope of the demonstration plant MASB have been completed.

The previous MASB tests have been performed at UTSI in a facility constructed to support the development of MHD power generation. Because of a loss of MHD funding, the UTSI facility closed last October. On February 2, 1999, Siemens Westinghouse proposed a 12-week study that would identify the cost of modifying the MASB for Lakeland low oxygen operation conditions and conducting tests 3 and 4 above at the Arnold Engineering Development Center (AEDC). On February 22, 1999, Siemens Westinghouse was given release to proceed with this study and study results/recommendations were received on April 22, 1999. Siemens Westinghouse recommends a two-phase test effort.

The first test effort would entail two 6-hour tests beginning November 1999 with the MASB operated with natural gas and "cold" compressor air. The MASB would be tested at full Lakeland pressure using the physical configuration planned for operation at lower pressure at Wilsonville in September 1999. As a result, the MASB test specimen will be a totally new unit (not a modification of a previously UTSI tested unit). The MASB would be installed in an existing AEDC test shell as shown in Fig. 1; although the internals 
currently installed within the shell would have to be removed and reinstalled at the completion of the first test phase, no major facility modifications external to the shell are needed.

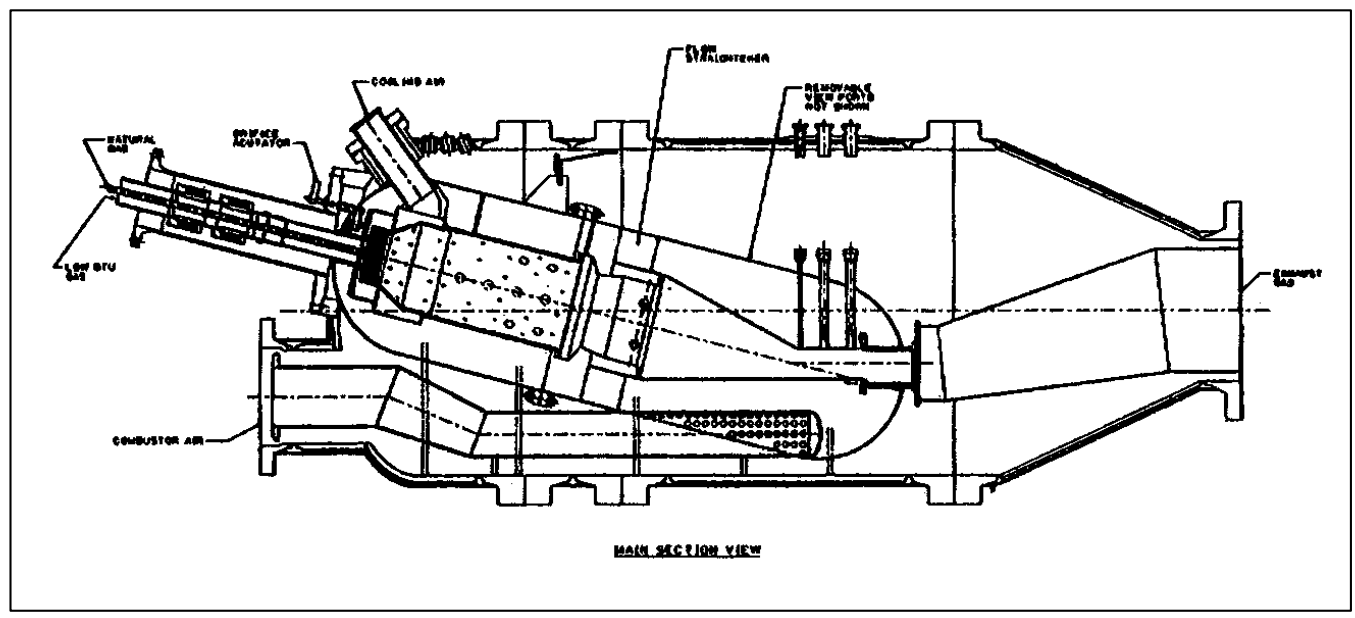

Figure 1 MASB in AEDC Test Rig

Although the second test effort was not the subject of this initial study, Siemens Westinghouse envisions it being conducted in another AEDC test cell that is currently mothballed. The facility has been well preserved and it will be modified to permit syngas testing with both cold and hot vitiated air; these tests would not be conducted until the fall 2000.

Written questions were submitted to Siemens Westinghouse regarding their proposed test programs; their responses and cost estimates were transmitted to the DOE on April 30, 1999.

Review of the proposed programs has revealed that they exceed existing funding limits, and Siemens has been asked to estimate the cost of consolidating the two into a single fall 2000 test. 
"This report was prepared as an account of work sponsored by an agency of the United States Government. Neither the United States Government nor any agency thereof, nor any of their employees, makes any warranty, express or implied, or assumes any legal liability or responsibility for the accuracy, completeness, or usefulness of any information, apparatus, product, or process disclosed, or represents that its use would not infringe upon privately owned rights. Reference herein to any specific commercial product, process, or service by trade name, trademark, manufacturer, or otherwise does not necessarily constitute or imply its endorsement by the United States Government or any agency thereof. The views and opinions of authors expressed herein do not necessarily state or reflect those of the United States Government or any agency thereof." 


\section{TECHNICAL PROGRESS REPORT NUMBER 21023R43 FOR MONTH 106 (August 1999) -- PHASE 3}

\section{Commercial Plant Design Update}

The Second-Generation PFB Combustion Plant conceptual design prepared in 1987 is being updated to reflect the benefit of pilot plant test data and the latest advances in gas turbine technology. The updated plant is being designed to operate with 95 percent sulfur capture and a single Westinghouse 501G gas turbine. Our 1987 study investigated two coal feeding arrangements, e.g., dry and paste feed. Paste feeding resulted in a lower cost of electricity. Paste, however, increases the water content of the carbonizer generated syngas; this increases the equilibrium partial pressure of hydrogen sulfide gas over calcium oxide/calcium carbonate and thereby reduces the carbonizer sulfur capture efficiency. Recognizing that the carbonizer and the CPFBC work together to control the plant overall sulfur capture efficiency, the higher CPFBC efficiency can compensate for the carbonizer's lower sulfur capture efficiency depending upon the amount of coal and/or char being fed to each unit. Since the latter are determined by the overall plant heat and material balance, we prepared a balance for each feed case to enable selection of the plant coal feed system.

As reported in the January Progress Report, "first cut" heat and material balances revealed a significant difference in efficiency between the paste and dry feed plants. Since dry feeding resulted in a significantly higher plant efficiency (45.2 vs. $41.3 \%$ ), it was decided to restrict further iterations to the dry feed case. Parsons reworked the steam cycle adding an additional extraction for a stand alone deaerator, split the boost air cooler into economizing and evaporative heat transfer zones, and increased the aggressiveness of the Spencer/Cotton/Cannon efficiency estimates. The result was a new system efficiency estimate of 46.4 percent HHV. The total gas flow through the gas turbine in the reworked plant is about $2 \%$ higher than that originally given to Siemens Westinghouse (SW). As a result, SW was asked to update their gas turbine power output.

All analyses conducted to date utilized a $1700 \mathrm{EF}$ carbonizer. Increasing the carbonizer temperature increases the conversion of coal to syngas energy resulting in less char energy for the steam cycle. Since reducing the size of the steam turbine relative to the gas turbine will increase the plant efficiency, syngas yield, heating value, and composition were determined for an 1800EF carbonizer. Using this new data Parsons generated "first cut" heat and material balance data for the plant and forwarded it to SW for gas turbine predictions in February. Using the new 1700EF and 1800EF carbonizer data SW forwarded new gas turbine performance data to Parsons. Insertion of the new data in the Parsons' plant model revealed further performance refinement was needed, and SW is addressing this need for refinement. 